\title{
Effect of Feeding Dried Distillers Grains with Solubles on Nutrient Utilization and Blood Biochemical Profile of Buffalo Calves
}

\author{
R.N. Chandrika ${ }^{1}$, Jasmine Kaur ${ }^{*}$, Chanchal Singh ${ }^{2}$, J.S. Lamba ${ }^{1}$ and R.S. Grewal ${ }^{1}$ \\ ${ }^{1}$ Department of Veterinary Physiology E Biochemistry, Guru Angad Dev Veterinary and Animal Sciences University, \\ Ludhiana, INDIA \\ ${ }^{2}$ Department of Animal Nutrition, Guru Angad Dev Veterinary and Animal Sciences University, Ludhiana, INDIA \\ "Corresponding author: J Kaur; E-mail: sachdeva_jasmine@rediffmail.com
}

Received: 04 May, 2021

Revised: 27 May, 2021

Accepted: 29 May, 2021

\begin{abstract}
A 90 day growth trial was conducted on 10-15 month old male buffalo (Murrah) calves (average initial body weight 252.92+17.0 $\mathrm{kg}$ ). Twelve calves were randomly distributed into three groups of four animals each. The animals in control group were fed with basal diet consisting of chopped wheat straw, berseem fodder and SBM based conventional concentrate mixture and animals in experimental groups 2 and 3 were fed wheat straw, berseem and concentrate mixtures in which SBM was replaced with DDGS at $50 \%$ and $75 \%$ levels on $\mathrm{N}$ basis, respectively. Digestibility of nutrients and nitrogen balance was comparable in all the groups, indicating RDDGS did not have any adverse effect on nutrient digestibility and nitrogen retention. RDDGS inclusion as a partial replacement of soybean meal had no deleterious effect on blood profile (total protein, cholesterol, triglycerides, BUN, glucose) and the values of all parameters were within the physiological range. Therefore, from the present study, it was concluded that RDDGS can replace soybean meal upto 75 percent in the concentrate mixture of buffalo calves on $\mathrm{N}$ basis without any adverse effect on palatability, digestibility of nutrients, nitrogen balance and health of the animals.
\end{abstract}

\section{HIGHLIGHTS}

0 Effect of rice dried distillers grains with solubles (RDDGS) in the diet of buffalo calves.

0 RDDGS can be used as replacement of soybean meal upto 75 percent without any adverse effect.

(0 Blood parameters were within normal physiological range.

Keywords: DDGS, Digestibility, blood profile

Livestock and dairy plays an important role in the economy and livelihood of people in India. Livestock contributes $25.6 \%$ of total value of output in agriculture which is $4.11 \%$ of total GDP (National livestock census, 2012). Around $60-70 \%$ of cost is involved in feeding. The cost of conventional feed resources used for feeding livestock has increased, because of increased needs of grains by the human population. Thus, there is a need to explore various alternate feed resources to meet the standards of feeding which do not compete with the human food so that the cost will be less. Growing biofuel production using cereals is also one of the reasons for high cost of grains. As the ethanol industry is growing fast, the quantity of the byproducts obtained also increases which may be available in abundance for less cost and can be used as the animal feed as some of them are rich sources of energy, protein and fat.

Dried distillers grains solubles (DDGS) is one such agroindustrial by-product obtained as a co-product in the production of bio-ethanol from various grains like maize, sorghum, wheat, rice and barley etc. Rice dried distillers grains solubles (RDDGS) is the major co-product from

How to cite this article: Chandrika, R.N., Kaur, J., Singh, C., Lamba, J.S. and Grewal, R.S. (2021). Effect of feeding dried distillers grains with solubles on nutrient utilization and blood biochemical profile of buffalo calves. J. Anim. Res., 11(3): 409-414.

Source of Support: None; Conflict of Interest: None 
alcohol and rice wine production using broken rice. DDGS can be included in the diet either as a protein source or an energy source, depending on the animal nutrient requirements, type of diet being fed, and economic considerations (Sahin et al., 2013). This by-product is a good source of rumen undegradable protein in the small intestine to complement ruminal microbial amino acids (Gao et al., 2015). Thus, it can be used as ruminant protein source in concentrate diets. Thus, the main objective of present experiment was to study the effect of rice DDGS as a replacement of soybean meal on growth performance and nutrient digestibility in male buffalo calves

\section{MATERIALS AND METHODS}

\section{Animal feeding}

A 90 day growth trial was conducted on 10-15 month old male buffalo (Murrah) calves (average initial body weight $252.92+17.0 \mathrm{~kg}$ ). Twelve calves were randomly distributed into three groups of four animals each. The animals in control group were fed with basal diet consisting of chopped wheat straw, berseem fodder and SBM based conventional concentrate mixture of and animals in experimental groups 2 and 3 were fed wheat straw, berseem and concentrate mixtures in which SBM was replaced with DDGS at 50\% and $75 \%$ levels on $\mathrm{N}$ basis, respectively. The ingredient composition of concentrate mixtures used in the present study is given in Table 1. The animals were housed in a concrete shed and were stall fed individually at 9:00 AM daily. The animals had free access to water twice daily. The daily record of feed intake and orts was maintained. The animals were weighed for 3 consecutive days every fortnight and the feeding schedule was revised accordingly. The animals in each group were fed as per ICAR (2013) feeding standard.

\section{Metabolic trial}

A 7-day metabolic trial was conducted on all the animals towards the end of growth trial. Samples of feedstuffs and orts were collected at $24 \mathrm{~h}$ interval and dried in duplicate at $100^{\circ} \mathrm{C}$ in a hot air oven. Samples of feed, faeces and orts were analyzed for total ash, $\mathrm{N}$ as per AOAC (2005), cellulose as per Crompton and Maynard (1938) and cell wall constituents given by Van Soest et al. (1991).

\section{Estimation of blood biochemical profile}

Blood samples were drawn from all buffalo calves at the end of experimental feeding from jugular vein. Serum was preserved at $-20^{\circ} \mathrm{C}$ to analyze the parameters viz. total protein, albumin, globulin, A: G, cholesterol, triglycerides, BUN, glucose.

\section{STATISTICAL ANALYSIS}

The data were subjected to one-way analysis of variance procedure using SPSS (2012), using the linear model. The post-hoc comparison of means was done for the significant difference by Tukey's b. Significant differences of treatments were considered at $\mathrm{P}<0.05$ level.

\section{RESULTS AND DISCUSSION}

Chemical composition of the concentrates, green fodder and wheat straw fed to the animals during the study was given in the Table 2 .

Table 1: Ingredient composition of concentrate mixtures (parts/100 parts)

\begin{tabular}{llll}
\hline Ingredient & Control & $\begin{array}{l}\text { T1 } \\
(\mathbf{5 0} \% \text { RDDGS) }\end{array}$ & $\begin{array}{l}\text { T2 } \\
\mathbf{( 7 5 \%} \text { DDGS) }\end{array}$ \\
\hline Maize & 34 & 34 & 34 \\
SBM & 15 & 7.5 & 3.75 \\
DDGS & 0 & 7.5 & 11.25 \\
Mustard Cake & 15 & 15 & 15 \\
Wheat Bran & 10 & 10 & 10 \\
Rice Polish & 6 & 6 & 6 \\
DORP & 17 & 17 & 17 \\
Mineral Mixture & 2 & 2 & 2 \\
Common Salt & 1 & 1 & 1 \\
\hline
\end{tabular}

Effect of dietary level of RDDGS on digestibility of nutrients in male buffalo calves

The DM intake and digestibility of DM with the inclusion of RDDGS in T1 (50\% RDDGS) and T2 (75\% RDDGS) groups was similar to that of control ( $0 \%$ RDDGS) group (Table 3). The results of the present study are in agreement with the results obtained by Kerckhove et al. (2011) where there was no change in DMD with DDGS supplemented diet in heifers. However, Benchaar et al. (2013) reported that the digestibility of $\mathrm{DM}$ increased $(\mathrm{P}<0.01)$ with 
Table 2: Chemical composition of feedstuffs offered during metabolism trial, \% DM basis

\begin{tabular}{llllll}
\hline Parameter & Control & $\begin{array}{l}\text { T1 } \\
\mathbf{( 5 0 \%} \text { RDDGS })\end{array}$ & $\begin{array}{l}\text { T2 } \\
\mathbf{( 7 5 \%} \text { RDDGS) }\end{array}$ & Green fodder & Wheat straw \\
DM & & 89.00 & 90.00 & 13.70 & 90.00 \\
OM & 88.00 & 92.10 & 92.15 & 87.40 & 91.30 \\
CP & 91.90 & 22.57 & 22.25 & 18.90 & 3.50 \\
EE & 22.10 & 5.08 & 5.01 & 3.50 & 1.68 \\
Total ash & 4.73 & 7.90 & 7.85 & 12.60 & 8.70 \\
NDF & 8.10 & 32.10 & 30.30 & 43.50 & 73.60 \\
ADF & 30.13 & 12.20 & 11.80 & 23.95 & 49.00 \\
Hemicellulose & 11.95 & 19.90 & 18.50 & 19.55 & 24.60 \\
TCHO & 18.18 & 64.45 & 64.89 & 65.00 & 86.12 \\
\hline
\end{tabular}

DM- Dry matter, OM-Organic matter, CP- Crude protein, EE- Ether extract, NDF- Neutral detergent fibre, ADF- Acid detergent fibre, TCHOTotal carbohydrates.

Table 3: Effect of dietary level of RDDGS on digestibility in male buffalo calves

\begin{tabular}{lllll}
\hline Parameter & C & T1 & T2 & SEM \\
\hline DMI, kg/d & 5.98 & 6.87 & 6.53 & 0.33 \\
\hline \multicolumn{1}{l}{ Digestibility of nutrients, \% } & & & 0.28 \\
\hline DM & 64.06 & 63.69 & 64.69 & 0.57 \\
OM & $67.45^{\mathrm{ab}}$ & $65.40^{\mathrm{a}}$ & $68.51^{\mathrm{b}}$ & 0.68 \\
CP & 73.18 & 71.39 & 71.31 & 1.00 \\
NDF & 51.61 & 48.47 & 52.88 & 2.27 \\
ADF & 41.31 & 36.34 & 36.07 & 1.28 \\
Cellulose & $57.12^{\mathrm{ab}}$ & $54.44^{\mathrm{a}}$ & $61.64^{\mathrm{b}}$ & 2.98 \\
Hemicellulose & 65.01 & 63.43 & 73.79 & 0.72 \\
TCHO & 65.91 & 64.03 & 67.88 & 0.40 \\
\hline Nutritive value & & & $62.69^{\mathrm{ab}}$ & 0.19 \\
\hline TDN, \% & $63.11^{\mathrm{b}}$ & $60.95^{\mathrm{a}}$ & 12.18 & \\
DCP, \% & 11.96 & 12.39 & & \\
\hline
\end{tabular}

TDN- Total digestible nutrients, DCP- Digestible crude protein, Means bearing different superscripts in a row differ significantly $(\mathrm{P}<0.05)$.

increase in DDGS supplementation in lactating cows. Murillo et al. (2016) also reported higher $(\mathrm{P}<0.05) \mathrm{DM}$ digestibility with the inclusion of corn DDGS in the ration of steers.

The organic matter digestibility was higher $(\mathrm{P}<0.05)$ in $\mathrm{T} 2$ (75\% RDDGS) group as compared to T1 (50\% RDDGS) group, however, it was similar to the control ( $0 \%$ RDDGS) group. The cellulose digestibility also followed similar trend and was higher $(\mathrm{P}<0.05)$ in T2 $(75 \%$ RDDGS $)$ group as compared to T1 (50\% RDDGS) group. The results of the present study are in accordance with the results of
Benchaar et al. (2013) where the OM digestibility was higher $(\mathrm{P}<0.01)$ in DDGS supplemented diets replacing corn and SBM in lactating cows. However, Castro perez et al. (2013) reported that the total tract OM digestion decreased $(\mathrm{P}<0.01)$ in diets where dry rolled corn and SBM were replaced by corn DDGS in male lambs.

No significant changes were observed in crude protein digestibility, neutral detergent fiber digestibility and acid detergent fiber digestibility as SBM was replaced by RDDGS in T1 (50\% RDDGS) and T2 (75\% RDDGS) groups (Table 3 ). The results obtained in the current study 
are in accordance with reports of Kerckhove et al. (2011) where the digestibilities of NDF and ADF didn't differ with DDGS supplemented diet in heifers, whereas the CP digestibility was higher $(\mathrm{P}=0.02)$ which disagrees with the present study of CP digestibility where there was no effect of RDDGS replacing SBM at 50\% and 75\% levels on CP digestibility. However, the CP digestibility in the present study was in agreement with report of Walter et al. (2012) where CP digestibility was unaffected by wheat DDGS in the diet of heifers. Benchaar et al. (2013) reported increase $(\mathrm{P}<0.01)$ in the digestibility of $\mathrm{CP}$ and NDF in diets of lactating cows where corn and SBM were replaced by DDGS which are disagreeing with the present study. No effect of RDDGS inclusion on hemicellulose and total carbohydrate digestibility in T1 (50\% RDDGS) and T2 (75\% RDDGS) groups was observed and were similar to that of control.

The total digestible nutrients $(\%)$ was higher $(\mathrm{P}<0.05)$ in control (0\% RDDGS) (63.12) than T1 (50\% RDDGS) (60.95) group, however, it was similar to that of T2 (75\% RDDGS) group. Omer et al. (2015) reported decrease $(\mathrm{P}<0.05)$ in TDN content as cotton seed meal was replaced by DDGS in calves, whereas, Wafaa and Mahmoud (2016) reported increased $(\mathrm{P}<0.05)$ TDN content with increasing DDGS level in lambs. The digestible crude protein (\%) didn't change with the inclusion of RDDGS in T1 $(50 \%$ RDDGS) and T2 (75\% RDDGS) groups in the current study. The results in the present study are in accordance with Wafaa and Mahmoud (2016) where changes in DCP were insignificant with the inclusion of DDGS in lambs, and disagrees with the results reported by Omer et al. (2015) where the DCP \% decreased $(\mathrm{P}<0.05)$ as cotton seed meal was replaced by DDGS in the diet of crossbred calves.

\section{Effect of dietary level of RDDGS on nitrogen balance in male buffalo calves}

The nitrogen intake in T1 (50\% RDDGS) and T2 (75\% RDDGS) groups was similar to that of control $(0 \%$ RDDGS) group indicating no effect of RDDGS inclusion on $\mathrm{N}$ intake (Table 4). Inclusion of RDDGS in T1 $(50 \%$ RDDGS) and T2 (75\% RDDGS) groups replacing SBM had no effect on faecal nitrogen excretion. In T1 (50\% RDDGS) group, the faecal $\mathrm{N}$ excretion (g/d) was numerically higher (54.68) than in T2 (75\% RDDGS)
(51.39) and control (0\% RDDGS) (42.71) group, however, the difference was not statistically significant. The nitrogen digested (g/d) in T1 (50\% RDDGS) (132.77) and T2 (75\% RDDGS) (126.97) groups was similar to that of control (0\% RDDGS) (135.14) and didn't change significantly with inclusion of RDDGS replacing SBM.

Table 4: Effect of dietary level of RDDGS on nitrogen balance $(\mathrm{g} / \mathrm{d})$ in male buffalo calves

\begin{tabular}{lllll}
\hline Parameter & C & T1 & T2 & SEM \\
\hline N intake & 177.85 & 187.45 & 178.36 & 6.21 \\
Faecal N & 42.71 & 54.68 & 51.39 & 2.74 \\
N digested & 135.14 & 132.77 & 126.97 & 4.22 \\
Urinary N & 78.20 & 66.45 & 64.68 & 3.55 \\
N balance & 56.94 & 66.32 & 62.29 & 3.01 \\
N retained (as \% of intake) & 31.92 & 35.23 & 35.09 & 1.06 \\
\hline
\end{tabular}

The urinary nitrogen $(\mathrm{g} / \mathrm{d})$ excretion in $\mathrm{T} 1$ (50\% RDDGS) (66.45) and T2 (75\% RDDGS) (64.68) groups was similar to control ( $0 \%$ RDDGS) (78.20) group (Table 5). The urinary $\mathrm{N}$ excretion decreased numerically with increasing RDDGS inclusion at 50\% and 75\% levels replacing SBM in the concentrate mixture.

Table 5: Effect of dietary level of RDDGS on blood profile of male buffalo calves

\begin{tabular}{lllll}
\hline Parameter & C & T1 & T2 & SEM \\
\hline Total protein, g/dl & 6.56 & 6.54 & 6.51 & 0.04 \\
Albumin, g/dl & 3.83 & 3.68 & 3.63 & 0.06 \\
Globulin, g/dl & 2.73 & 2.87 & 2.89 & 0.06 \\
A:G & 1.43 & 1.28 & 1.26 & 0.05 \\
Cholesterol, mg/dl & 79.53 & 71.00 & 73.70 & 2.25 \\
Triglycerides, mg/dl & 18.67 & 20.35 & 22.09 & 1.35 \\
BUN, mg/dl & 25.07 & 25.96 & 21.73 & 1.02 \\
Glucose, $\mathrm{mg} / \mathrm{dl}$ & 45.85 & 43.93 & 44.90 & 0.87 \\
\hline
\end{tabular}

The nitrogen balance (g/d) in T1 (50\% RDDGS) (66.32) and T2 (75\% RDDGS) (62.29) groups was numerically higher as compared to control (0\% RDDGS) (56.94) group, but the difference was not statistically significant. The nitrogen retained (as \% of intake) in T1 ( $50 \%$ RDDGS) (35.23) and T2 (75\% RDDGS) (35.09) groups was similar to that of control ( $0 \%$ RDDGS) (31.92) group.

The total nitrogen intake, faecal and urinary nitrogen excreted, nitrogen digested, nitrogen balance and nitrogen 
retention didn't change significantly in the present study with inclusion of RDDGS at 50\% and $75 \%$ levels replacing SBM in T1 and T2 groups, respectively. The results of present study are in agreement with the results obtained by Geron et al. (2017) and Obeidat (2017) where the inclusion of corn DDGS didn't alter the nitrogen intake, faecal and urinary $\mathrm{N}$ excreted, nitrogen balance and \% nitrogen retention in sheep.

Effect of dietary level of RDDGS on blood profile of male buffalo calves

Effect of DDGS supplementation on blood glucose, triglycerides, total protein, blood urea-nitrogen, cholesterol is presented in Table 5.

No significant changes were observed in the blood glucose, triglycerides, total protein, albumin, globulin, blood urea-nitrogen and cholesterol parameters with the supplementation of RDDGS in T1 (50\% RDDGS) and T2 (75\% RDDGS) replacing SBM in the concentrate mixture.

The total protein ranged between 6.51 and 6.56 which is within the normal physiological range (Table 5). The results obtained in the present study are in agreement with reports of Wafaa and Mahmoud (2016) and Obeidat (2017) where there was no significant effect of corn DDGS on blood parameters (total protein, albumin and globulin) in the diet of lambs. The concentration of plasma triglycerides (which is the storage form of fat within the body) in T1 (50\% RDDGS) and T2 (75\% RDDGS) groups was similar to that of control ( $0 \%$ RDDGS) group. Blood glucose which reflects the energetic status of ruminants, ranged from 43.93 to 45.85 in the present study. The results in the present study are contradictory to the results of Omer et al. (2015) where the globulins, triglycerides and glucose concentrations decreased $(\mathrm{P}<0.05)$ with inclusion of DDGS replacing cotton seed meal in crossbred calves. Concentration of urea- $\mathrm{N}$ in blood serum is an indicator of the adequacy or inadequacy of the nitrogen in the diet of animals (Hammond 1983). The inclusion of RDDGS in $\mathrm{T} 1$ (50\% RDDGS) and T2 (75\% RDDGS) groups replacing SBM in concentrate mixtures had no significant effect on blood urea N (BUN) concentration. The serum urea nitrogen concentration is closely associated with the breakdown of protein to amino acids and their deamination in rumen and the rate of utilization of $\mathrm{NH}_{3}$ for bacterial protein synthesis. The results obtained in the present study are not in agreement with results of Omer et al. (2015) where the urea activity and $\mathrm{A} / \mathrm{G}$ ratio increased $(\mathrm{P}<0.05)$ with inclusion of DDGS replacing cotton seed meal in cross bred calves.

\section{Effect of dietary level of RDDGS on performance of animals}

The body weight gain in 90 days was numerically higher in T2 (75\% RDDGS) (87.31) than T1 (50\% RDDGS) (86.02) and control ( $0 \%$ RDDGS) (74.35) groups, indicating that RDDGS was not having any adverse effect on body weight of male buffalo calves (Table 6).

Table 6: Effect of dietary level of RDDGS on changes in body weight $(\mathrm{kg})$ of male buffalo calves

\begin{tabular}{lllll}
\hline Parameter & C & T 1 & T 2 & SEM \\
Initial body weight & 253.46 & 253.17 & 252.13 & 17.01 \\
Final body weight & 327.81 & 339.19 & 339.44 & 18.45 \\
BW gain in 90 days & 74.35 & 86.02 & 87.31 & 2.93 \\
ADG, g & 826.16 & 955.79 & 970.14 & 32.52 \\
FCR & 7.55 & 6.94 & 6.62 & 0.31 \\
\hline
\end{tabular}

The average daily gain (g) in T2 (75\% RDDGS) (970.14) was numerically higher than T1 (50\% RDDGS) (955.79) and control ( $0 \%$ RDDGS) (826.16) group, though the difference was statistically insignificant (Table 6). The FCR improved with increase in the RDDGS level replacing $\mathrm{SBM}$ in T1 (50\% RDDGS) (6.94) and T2 (75\% RDDGS) (6.62) groups as compared to control (0\% RDDGS) (7.55) group. The results obtained in the present study are in agreement with results of Tamilee (2013) who reported no differences in body weights and ADG when corn DDGS was included in diet of dairy heifers.

\section{CONCLUSION}

It was concluded that RDDGS can replace soybean meal upto 75 percent in the concentrate mixture of buffalo calves on $\mathrm{N}$ basis without any adverse effect on palatability, digestibility of nutrients, nitrogen balance and health of the animals.

\section{REFERENCES}

AOAC. 2000. Official methods of analysis. $17^{\text {th }}$ ed. Association of official analytical chemists, Washington DC: AOAC International. 
Benchaar, C., Hassanat, F., Gervais, R., Chouinard, P.Y., Julien, C., Petit, H.V. and Masse, D.I. 2013. Effects of increasing amounts of corn dried distillers grains with solubles in dairy cow diets on methane production, ruminal fermentation, digestion, N balance, and milk production. J. Dairy Sci., 96: 2413-27.

Castro-Perez, B.I., Garzon-Proano, J.S., Lopez-Soto, M.A., Barreras, A., Gonzalez, V.M., Plascencia, A., Estrada-Angulo, A., Davila-Ramos, H., Rios-Rincon, F.G. and Zinn, R.A. 2013. Effects of replacing dry-rolled corn with increasing levels of corn dried distillers grains with solubles on characteristics of digestion, microbial protein synthesis and digestible energy of diet in hair lambs fed high-concentrate diets. Asian Australas J. Anim. Sci., 26(8): 1152-59.

Crompton, E.W. and Maynard, Z.A. 1938. The relation of cellulose and lignin content to the nutritive value of animal feeds. J. Nutr., 15: 383-95.

Gao, W., Chen, A., Zhang, B., Kong, P., Liu, C., and Zhao, J. 2015. Rumen degradability and post-ruminal digestion of dry matter, nitrogen and amino acids of three protein supplements. Asian Australas J. Anim. Sci., 28(4): 485-493.

Geron, J.V., Garcia, J., Martins Coelho, K.S., Sílvia Cristina de, G., Moura Zanine, A., de Souza, A.L., Carvalho, J.T.H., Roberto, L.S., Neto, E.L.S. and Ferreira, D.J. 2017. Distiller's dried grains with solubles (Zea mays L.) in feeding sheep on nitrogen balance. Ciências Agrárias., 38(6): 3807-16.

Hammond, A.C. 1983. The use of blood urea nitrogen concentration as an indicator of protein status in cattle. Bovine Pract., 18: 114

ICAR. 2013. Nutrient requirements of cattle and buffalo. Indian Council of Agricultural Research, New Delhi.

Kerckhove, A.V., Lardner, H.A., Yu, P., McKinnon, J.J. and Walburger, K. 2011. Effect of dried distillers grain, soybean meal and grain or canola meal and grain-based supplements on forage. Can. J. Anim. Sci., 91: 123-32.

Murillo, M., Herrera, E., Ruiz, O., Reyes, O., Carrete, F.O. and Gutierrez, H. 2016. Effect of supplemental corn dried distillers grains with solubles fed to beef steers grazing native rangeland during the forage dormant season. Asian Australas J. Anim. Sci., 29(5): 666-73.
National Livestock census. 2012. 19 $9^{\text {th }}$ Livestock census. All India report. Ministry of Agriculture, Department of Animal Husbandry, Dairying and Fisheries, Krishi Bhawan, New Delhi.

Obeidat, B.S. 2017. Influence of corn-dried distiller's grain with solubles on growth performance and blood metabolites of Awassi lambs offered a concentrate diet. Italian J. Anim. Sci., 24: 1-7.

Omer, H.A.A., Soha, S., Abdel M., EL-Nomeary, Y.A.A., Somia, A., Nassar, S.M., Nasr Hala A.A. and Abou, Z. 2015. Nutritional impact of partial replacement of cotton seed meal with distillers dried grain with solubles (DDGS) on animal performance, digestion coefficients and some blood constituents in crossbred calves. World Appl. Sci. J., 33(4): 580-89.

Sahin, T., Kaya, O., Aksu Elmali, D. and Kaya, I. 2013. Effects of dietary supplementation with distiller dried grain with solubles in growing lambs on growth, nutrient digestibility and rumen parameters. Revue de Médecine Véterinaire., 164(4): 173-78.

Satter, L.D. and Roffler, R.E. 1976. Relationship between ruminal ammonia and the protein nitrogen utilization by ruminants. In Proceedings of Res. Co-ordinative Meeting. FAO/IAEA, Vienna Austria, pp. 119.

SPSS. 2012. Statistical Packages for Social Sciences Version 21.0.SPSS Inc. Chicago, IL, USA.

Tamilee, N. 2013. Feeding distillers grain to young dairy heifers. Purdue extension.

Van Soest, P.J., Robertson, J.B. and Lewis, B.A. 1991. Methods for dietary fiber, neutral detergent fiber and non starch polysaccharides in relation to animal nutrition. J. Dairy Sci., 74: 3583-3597.

Wafaa, M.A.G. and Mahmoud, A.E.M. 2016. Impact of dried distillers grains with solubles on productive performance of Barki lambs. Egyptian. J. Nutr. Feeds., 19(1): 31-40.

Walter, L.J, McAllister, T.A., Yang, W.Z., Beauchemin, K.A., He, M. and McKinnon, J.J. 2012. Comparison of wheat or corn dried distillers grains with solubles on rumen fermentation and nutrient digestibility by feedlot heifers. J. Anim. Sci., 90: 1291-1300. 